\title{
Calcium-binding protein in bull seminal vesicle secretion and seminal plasma
}

\author{
J. Lukač, M. Pribanić* and E. Koren \\ Laboratory for Experimental Medicine, University of Zagreb, Domagojeva 2, \\ and ${ }^{*}$ Faculty of Pharmacy and Biochemistry, 41000 Zagreb, Yugoslavia
}

\begin{abstract}
Summary. A protein which showed high affinity for calcium ions was isolated from bull seminal vesicle secretion and seminal plasma. Its calcium-binding activity depended on the ionic strength and $\mathrm{pH}$ of the medium. The dissociation constant was $7.7 \times 10^{-7} \mathrm{M}$ and there were 14 binding sites per protein molecule. The molecular weight of calcium-binding protein from bull seminal vesicle secretion, estimated by the gel filtration method, was 110,000 . The protein may be involved in the regulation of the calcium ion level in seminal plasma.
\end{abstract}

\section{Introduction}

A number of calcium-binding proteins is known to exist in mammals. Their common characteristic is a specific binding of and high affinity for calcium ions. The calcium-binding protein from the sarcoplasmic reticulum, for example, is capable of binding large amounts of calcium ions, and is thus important for muscle contraction. Some other calcium-binding proteins play an important role in calcium transport in the body (Siegel, 1973).

This paper presents data on a protein isolated from bull seminal vesicle secretions and seminal plasma which appears to have the characteristics of a calcium-binding protein.

\section{Materials and Methods}

Bull seminal vesicle secretion was obtained from sexually mature Siemental bulls by manual expression of the seminal vesicle 2-3 hr after killing the animals in a slaughterhouse. Semen was collected by using an artificial vagina and the seminal plasma was separated immediately by centrifugation at $1100 \mathrm{~g}$ for $10 \mathrm{~min}$. Seminal vesicle secretion and seminal plasma specimens were used within $3 \mathrm{hr}$ or stored at $-20^{\circ} \mathrm{C}$.

\section{Isolation of calcium-binding protein $(\mathrm{CaBP})$}

Aliquots of $0.5 \mathrm{ml}$ seminal vesicle secretion or seminal plasma were mixed with $9.5 \mathrm{ml} 0.02 \mathrm{M}$-tris$\mathrm{HCl}$ buffer, $\mathrm{pH} 4.5$, and left to stand at $20^{\circ} \mathrm{C}$ for $10 \mathrm{~min}$. The precipitate formed was separated by centrifugation (for $10 \mathrm{~min}$ at $1100 \mathrm{~g}, 20^{\circ} \mathrm{C}$ ), washed 3 times with $10 \mathrm{ml}$ of the same buffer and, after the last centrifugation, dissolved in $5 \mathrm{ml} 0 \cdot 15 \mathrm{M}$-tris- $\mathrm{HCl}$ buffer, $\mathrm{pH} 7 \cdot 0$. This solution was dialysed against $500 \mathrm{ml} 0.15 \mathrm{M}$-tris- $\mathrm{HCl}$ buffer, $\mathrm{pH} 7 \cdot 0$, for $48 \mathrm{hr}$ at $4^{\circ} \mathrm{C}$ with constant magnetic stirring. During the dialysis the dialysing buffer was changed every $8 \mathrm{hr}$. The dialysed protein, i.e. the solution containing CaBP, was analysed by polyacrylamide gel electrophoresis and the concentration determined. If not used immediately, it was stored at $-20^{\circ} \mathrm{C}$.

\section{Assay of calcium-binding activity}

Calcium-binding activity was determined by the equilibrium dialysis procedure using (A) the classical method with dialysis bags, or (B) an equilibrium dialyser (Hoefer Scientific Instruments). 
(A) Samples $(0.5 \mathrm{ml})$ of CaBP solution, containing $0.6-0.8 \mathrm{mg}$ protein, were placed into small dialysing bags (A. H. Thomas \& Co., Philadelphia, U.S.A.; $6 \mathrm{~mm}$ diam.) which had been boiled for $1 \mathrm{hr}$ in deionized water before use. The samples were dialysed against $50 \mathrm{ml} 0.15 \mathrm{M}$-tris- $\mathrm{HCl}$ buffer containing $0 \cdot 1 \mathrm{mM}-\mathrm{CaCl}_{2}$ and $0.0284 \mu \mathrm{Ci}^{45} \mathrm{Ca} / \mathrm{ml}$. The dialysis was performed for $12 \mathrm{hr}$ at $21^{\circ} \mathrm{C}$ with constant magnetic stirring of the outer solution.

(B) To $0.5-\mathrm{ml}$ aliquots of CaBP solution, containing $0.6-0.8 \mathrm{mg}$ protein, $10-\mu$ aliquots of ${ }^{45} \mathrm{CaCl}$ solution $(0.0284 \mu \mathrm{Ci})$ were added. The samples were then placed into dialysing chambers (vol. $=0.7 \mathrm{ml}$ ) separated by dialysing membranes from identical chambers containing $0.15 \mathrm{M}$-tris$\mathrm{HCl}$ buffer, $\mathrm{pH} 7 \cdot 0$. Dialysis was performed at $20^{\circ} \mathrm{C}$ for $12 \mathrm{hr}$. Mixing was provided by constant slow rotation of the device.

After this period, in both procedures, $100-\mu \mathrm{l}$ samples were taken, in triplicate, from the CaBP solution and the protein-free solution for radioactivity measurements. The samples were transferred into counting vials containing $5 \mathrm{ml}$ Bray's solution (Bray, 1960) and left to stand at $20^{\circ} \mathrm{C}$ for $72 \mathrm{hr}$. Radioactivity was measured in a Mark II (Nuclear Chicago) liquid scintillation counter.

$\mathrm{CaBP}$ binding activity was studied as a function of $\mathrm{pH}$ (by Procedure $\mathrm{A}$ ), ionic strength and $\mathrm{CaCl}_{2}$ concentrations (by Procedure B). CaBP binding activity was also determined at various concentrations of $\mathrm{MgCl}_{2}, \mathrm{BaCl}_{2}$, and $\mathrm{SrCl}_{2}$ (by Procedure B). The binding data are expressed as the ratio of protein-bound calcium to unbound calcium, according to the equation: bound ${ }^{45} \mathrm{Ca} /$ unbound ${ }^{45} \mathrm{Ca}=$ $\left({ }^{45} \mathrm{Ca}\right)_{\mathrm{P}}-\left({ }^{45} \mathrm{Ca}\right)_{\mathrm{B}} /\left({ }^{45} \mathrm{Ca}\right)_{\mathrm{B}}$ where $\left({ }^{45} \mathrm{Ca}\right)$ represents the radiocalcium concentration in $\mathrm{d} / \mathrm{min}$ and subscripts $\mathrm{P}$ and $\mathrm{B}$ designate the $\mathrm{CaBP}$ solution and solution without protein, respectively.

\section{Molecular weight determination}

The molecular weight of CaBP was determined by gel filtration on Sephadex G-200 (Pharmacia, Uppsala, Sweden) and the $V_{e} / V_{o}-\log$ molecular weight plot. The column $(0.8 \times 28 \mathrm{~cm})$ was calibrated with dextran blue (Pharmacia), mol.wt $2 \times 10^{8}$; bovine serum albumin (Sigma Chemicals, U.S.A.), mol. wt $6.8 \times 10^{4}$; cytochrome $\mathrm{C}$ (National Biochemicals, U.S.A.), mol. wt $1.3 \times 10^{4}$; and potassium dichromate (Merck, Germany), mol. wt $2.94 \times 10^{2}$.

Polyacrylamide gel electrophoresis was performed by the method of Reisfeld, Lewis \& Williams (1962) on $10 \%$ polyacrylamide gels at $\mathrm{pH} 8.3$. Protein concentrations were determined by the method of Lowry, Rosebrough, Farr \& Randall (1951). The solution containing $2.84 \mu \mathrm{Ci}^{45} \mathrm{CaCl}_{2} / \mathrm{ml}$ was purchased from the Radiochemical Centre, Amersham, England.

\section{Results}

Bull seminal vesicle secretion showed 6 protein bands on polyacrylamide electrophoresis (Plate 1, Gel 1). A similar electrophoretic pattern was obtained with bull seminal plasma (Plate 1, Gel 2). The protein concentration was $60-95 \mathrm{mg} / \mathrm{ml}$ seminal vesicle secretion and $60-70 \mathrm{mg} / \mathrm{ml}$ seminal plasma, and both fluids had a $\mathrm{pH}$ of 6.5 .

The most abundant protein fraction from seminal vesicle secretion and seminal plasma was isolated by precipitation at $\mathrm{pH} 4.5$ (Plate 1 , Gel 3). This protein accounted for $35 \%$ of all proteins, as revealed by densitometry of gels, and showed calcium-binding activity. We therefore called it calciumbinding protein $(\mathrm{CaBP})$. It has a molecular weight of about 110,000 . After precipitation from seminal vesicle secretion or seminal plasma at $\mathrm{pH} 4 \cdot 5, \mathrm{CaBP}$ could not be demonstrated by polyacrylamide gel electrophoresis, while all the other protein bands were present (Plate 1, Gel 4). Seminal vesicle secretion and seminal plasma deprived of $\mathrm{CaBP}$ had a calcium-binding activity 5 times less than that in intact samples.

The calcium-binding activity of CaBP was greatest in the pH 6-7 range (Table 1). As shown in Table 2 the binding activity of $\mathrm{CaBP}$ diminished with the increase in ionic strength. The CaBP saturation curve is shown in Text-fig. 1, and the Scatchard plot (Scatchard, 1949), from which $K_{\mathbf{D}}$ was found to be approximately $7 \cdot 7 \times 10^{-7} \mathrm{M}$, shows that the number of binding sites is 14 (Text-fig. 2 ). The influence of strontium, barium and magnesium ions on CaBP binding activity is shown in Table 3 . 
PLATE 1

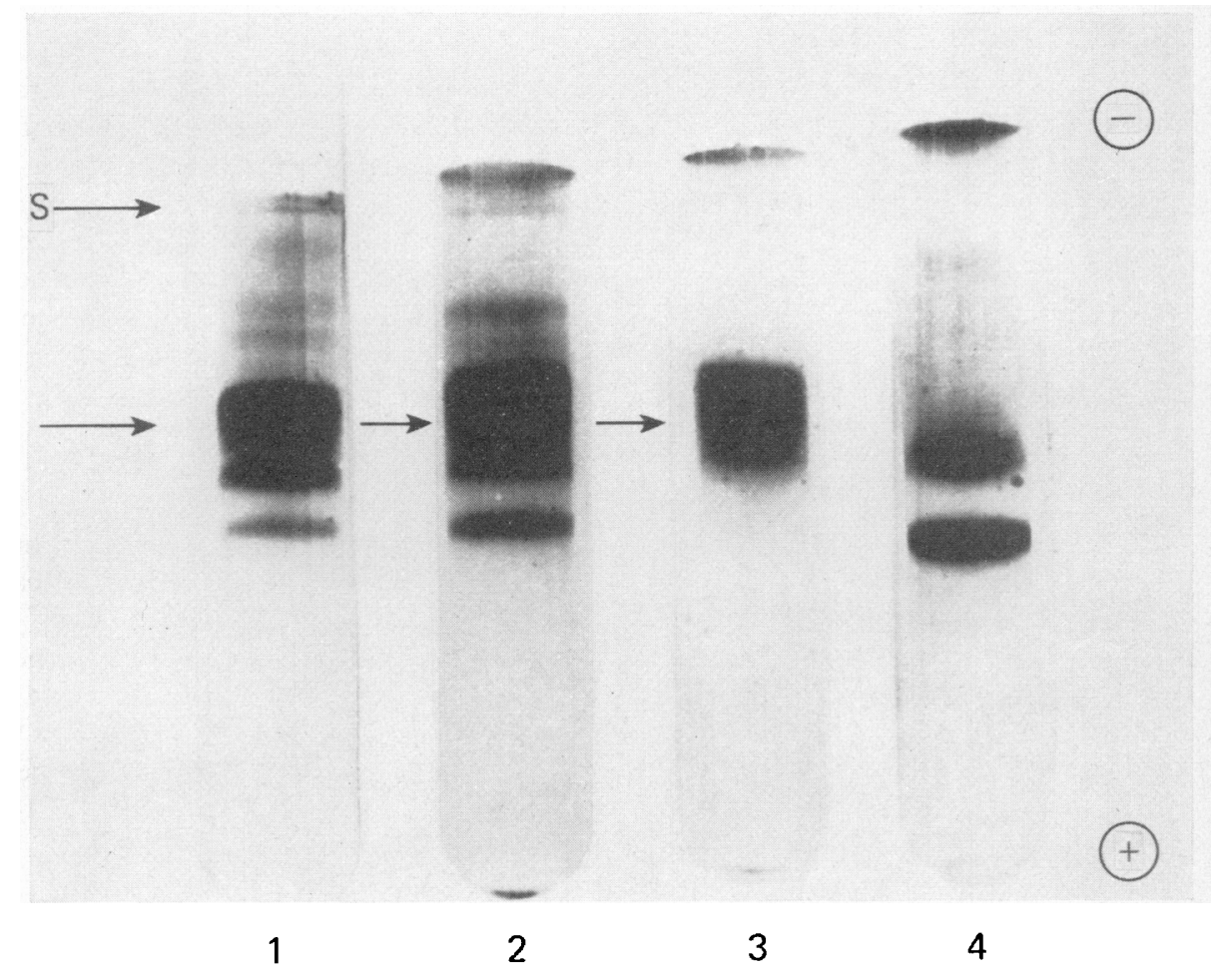

Disc electrophorograms of (1) $5 \mu \mathrm{I}$ bull seminal vesicle secretion containing $230 \mu \mathrm{g}$ protein; (2) $5 \mu \mathrm{l}$ bull seminal plasma containing $190 \mu \mathrm{g}$ protein; (3) $100 \mu \mathrm{l} \mathrm{CaBP}$ solution containing $220 \mu \mathrm{g}$ protein obtained from seminal plasma; and (4) $100 \mu \mathrm{l} \mathrm{CaBP-deprived} \mathrm{seminal} \mathrm{plasma} \mathrm{containing} 290 \mu \mathrm{g}$ protein. In Gels 1 and 2 six protein bands are present. In Gel 3 only the most abundant protein fraction (CaBP) is visible. An identical electrophoretic pattern was obtained with CaBP derived from seminal vesicle secretion. In Gel 4 the absence of the CaBP band is evident. $S=$ start; the arrows point to the CaBP band. 
Table 1. The effect of $\mathrm{pH}$ on the calcium-binding activity of a protein from bull seminal vesicle secretions at constant calcium concentration

\begin{tabular}{lcccccc}
\hline pH & 4 & 5 & 6 & 7 & 8 & 9 \\
Bound ${ }^{45} \mathrm{Ca}$ : unbound ${ }^{45} \mathrm{Ca}$ & 0.028 & 0.05 & 0.070 & 0.086 & 0.070 & 0.035 \\
\hline
\end{tabular}

Table 2. The effect of various $\mathrm{NaCl}$ concentrations on the calcium-binding activity of a protein from bull seminal vesicle secretions at constant protein and calcium concentrations

\begin{tabular}{lllll}
\hline lonic strength & 0.02 & 0.05 & 0.10 & 0.15 \\
Bound ${ }^{45} \mathrm{Ca}:$ unbound ${ }^{45} \mathrm{Ca}$ & $\mathbf{0 . 2 1 0}$ & 0.135 & 0.115 & 0.083
\end{tabular}

Table 3. The effect of various concentrations (mM) of $\mathrm{SrCl}_{2}, \mathrm{MgCl}_{2}$ and $\mathrm{BaCl}_{2}$ on the calcium-binding activity of a protein from bull seminal vesicle secretions

\begin{tabular}{|c|c|c|c|c|c|c|c|c|c|}
\hline & \multicolumn{3}{|c|}{$\mathrm{SrCl}_{2}$} & \multicolumn{3}{|c|}{$\mathbf{M g C l}_{2}$} & \multicolumn{3}{|c|}{$\mathrm{BaCl}_{2}$} \\
\hline & $0 \cdot 1$ & 0.5 & $1 \cdot 0$ & 0.1 & 0.5 & $1 \cdot 0$ & $0 \cdot 1$ & 0.5 & 1.0 \\
\hline Bound ${ }^{45} \mathrm{Ca}$ : unbound ${ }^{45} \mathrm{Ca}$ & 0.052 & 0.035 & 0.020 & 0.068 & 0.075 & 0.077 & 0.065 & 0.050 & 0.0457 \\
\hline
\end{tabular}

\section{Discussion}

Bull seminal vesicle secretion and bull seminal plasma are clearly shown to contain a calcium-binding protein which can be easily isolated from both sources by precipitation at $\mathrm{pH} 4.5$, a value probably very close to its isoelectric point. The other proteins in seminal vesicle secretion and seminal plasma do not appear to possess any appreciable calcium-binding activity.

The results obtained in our study point to some characteristics of $\mathrm{CaBP}$ and the mechanism of its interaction with calcium ions.

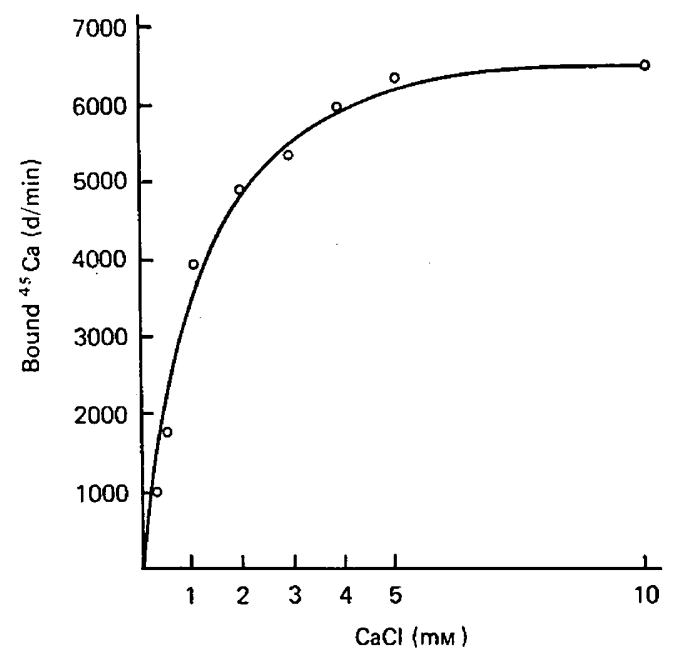

Text-fig. 1. Saturation curve of the calcium-binding protein (CaBP) from bull seminal vesicle secretions. Ionic strength $=0.15 ;$ protein concentration $=1.6 \mathrm{mg} / \mathrm{ml}$. 


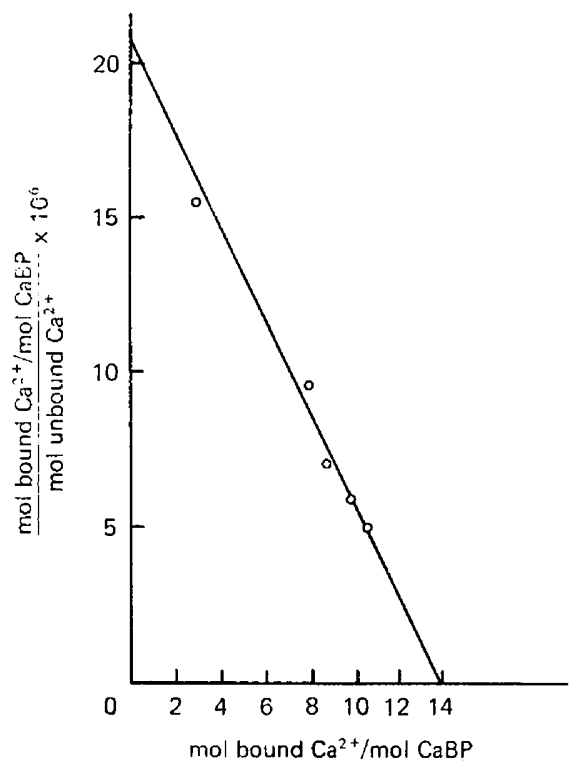

Text-fig. 2. Saturation analysis of the calcium-binding protein (CaBP) from bull seminal vesicle secretions. $K_{\mathrm{D}}=7 \cdot 7 \times 10^{-7} \mathrm{M} ;$ binding sites number $=14$; ionic strength $=0.15 ;$ protein concentration $=1.6 \mathrm{mg} / \mathrm{ml}$.

Calcium is known to favour complexes of coordination number 8 for oxygen donor ligands, such as the carboxylate group and the carbonyl group of the peptide bond where the bonding is essentially electrostatic (Williams, 1970; Cotton \& Wilkinson, 1972; Rao, Gurundath Rao \& Reddy, 1975; Siegel, 1973; Makinen, 1975). The binding ability of $\mathrm{CaBP}$ for $\mathrm{Ca}^{2+}$ indicates that $\mathrm{CaBP}$ may contain oxygen donor groups such as carboxylate, phosphate or sulphonate. The same groups render CaBP soluble in water via hydrogen bonding with solvent molecules. The increase in ionic strength ensures that other cations compete with $\mathrm{Ca}^{2+}$ for attachment at binding sites in $\mathrm{CaBP}$ and therefore the bound amount of $\mathrm{Ca}^{2+}$ decreases as shown in Table 2 .

The most favourable $\mathrm{pH}$ for $\mathrm{Ca}^{2+}$ binding to $\mathrm{CaBP}$ was found to be near $7 ; \mathrm{H}^{+}$and $\mathrm{OH}^{-}$interfere with calcium binding, since of all cations protons have the highest binding energies with ligands such as carbonyl (Williams, 1971 ; Rao et al., 1975). The interference of hydroxide ions might be rationalized in terms of the co-ordination of $\mathrm{OH}^{-}$to the $\mathrm{Ca}^{2+}$ ion. The hydroxide ion is capable of forming bridges between metal ions (Cotton \& Wilkinson, 1972) and therefore it may compete with CaBP for $\mathrm{Ca}^{2+}$. The $\mathrm{Ca}(\mathrm{OH})^{+}$ion compared to the $\mathrm{Ca}^{2+}$ ion is a weaker competitor for binding at oxygen electron donor sites.

Magnesium appears to have only a weak tendency for oxygen donor groups and is known to bind preferentially to nitrogen bases (Williams, 1970). Strontium and barium ions obviously compete successfully with calcium ions for binding sites. The effect of strontium is greater than that of barium since the charge:radius ratio of calcium $(2 \cdot 0)$ is closer to that of strontium (1.8) than to that of barium (1·5) (Cotton \& Wilkinson, 1972).

In comparison with known calcium-binding proteins, CaBP from bull seminal vesicle secretion and seminal plasma displays rather high specificity and binding capacity. Only the calcium-binding protein from the sarcoplasmic reticulum has a greater binding site number (43) (Siegel, 1973). Bull seminal vesicle secretion and seminal plasma CaBP most probably originate from the seminal vesicle epithelium, which is also known to be responsible for the secretion of calcium ions (Mann, 1964). It is possible that $\mathrm{CaBP}$ plays some role in the secretion of calcium ions, or is related to the high calcium ion concentration (10-43 mg/ml) in the seminal plasma (Cragle, Salisbury \& Muntz, 1958; Cragle, Salisbury \& VanDemark, 1958). A higher calcium and magnesium ion content is known to influence the sperm negative charge, thus producing conditions for sperm clumping (Muzikant \& Hronová, 1968). In such cases CaBP could act as a 'buffer' preventing excessive calcium ion concentrations. 
This work was supported in part by research grant No. 720-0440 from the Ford Foundation, New York, and grant No. IV/3 from the Croatian Republican Research Fund.

\section{References}

BraY, G.A. (1960) A simple efficient liquid scintillator for counting aqueous solutions in a liquid scintillation counter. Analyt. Biochem. 1, 279.

Cotron, F.A. \& Wilkinson, G. (1972) Advanced Inorganic Chemistry, 3rd edn, pp. 206, 406. Interscience Publishers, New York.

Cragle, R.G., Salisbury, G.W. \& Muntz, J.H. (1958) Distribution of bulk and trace minerals in bull reproductive tract fluids and semen. J. Dairy Sci. 41, 1273-1277.

Cragle, R.G., Salisbury, G.W. \& VanDemark, N.L. (1958) Sodium, potassium, calcium and chloride distribution in bovine semen. J. Dairy Sci. 41, 12671272.

LOWRY, O.H., ROSEbrough, N.Y., FARR, A.L. \& RANDALL, R.J. (1951) Protein measurement with the Folin phenol reagent. J. biol. Chem. 193, 265275.

MAKINEN, M.W. (1975) Structural and electronic aspects of metal ions in proteins. In Techniques and Topics in Bioinorganic Chemistry, p. 90. Ed. C. A. McAuliffe. McMillan, London.

MANN, T. (1964) The Biochemistry of Semen and of the Male Reproductive Tract, 2nd edn. Methuen, London.
MuZikant, J. \& Hronoví, B. (1968) Calcium and magnesium concentrations in semen and seminal plasma of bulls, boars and rabbits and their changes in exhaustive collections. Docum. vet. Brno. 7, 239246.

RaO, C.N.R., Gurundath Rao, K. \& Reddy, N.V.R. (1975) Spectroscopic studies of ion solvation. Interaction of alkali and alkaline earth cations and protons with electron donors. J. Am. Chem. Soc. 97, 29182919.

Reisfeld, R.A., Lewis, V.J. \& Williams, D.E. (1962) Disc electrophoresis of basic proteins and peptides on polyacrylamide geis. Nature, Lond. 195, 281-290.

SCATCHARD, G. (1949) The attractions of protons for small molecules and ions. Ann. N.Y. Acad. Sci. 51, 660-672.

SIEGEL, F.L. (1973) Calcium binding proteins. In Structure and Bonding, Vol. 17, pp. 221, 223. Eds. J. D. Dunitz \& P. Hemmerick. Springer Verlag, Berlin.

Williams, R.J.P. (1970) The biochemistry of sodium, potassium, magnesium and calcium. Quart. Rev. 24, 331-365.

Williams, R.J.P. (1971) Biochemistry of Group IA and IIA cations. Adv. Chem. Ser. No. 100.

Received 22 January 1976 